\title{
THE FOREST OFFENCES AND THE NATIONAL SECURITY OF ROMANIA
}

\author{
Anca Elena BENȚA
}

\author{
„Alexandru Ioan Cuza” Police Academy, Bucharest, Romania \\ ancabenta@yahoo.com
}

\begin{abstract}
In the last 25 years, we have assisted to an increase of the criminal actions in the forestry field. The factors generating the criminal phenomenon in the above mentioned field are social, economic, to which we can add the lack in people's education, as well as some persons' mentality and, last but not least, we mention poverty and the wish to get rich under any circumstances. The prevailing factor is corruption existing at all levels, some people's eagerness of easily gained wealth and the lack of involvement of the government institutions, which were supposed to take measures in this respect. In many cases, the forestry criminal actions were undertaken with the help of certain representatives of judicial organs or public institutions and authorities of the state. Illegal cutting of trees, illegal deforestation and inappropriate forestry become a new threat to the national security of Romania. The new Forestry Code makes provisions for the illegal actions that are considered criminal offences and for the criminal sanctions for committing forestry crimes. These illegal actions have serious consequences: financial, for the environment, for the national security, requiring measures to reduce them and to fight against their negative effects.
\end{abstract}

\section{Keywords: forest offences, threats, national security}

\section{Introduction}

Scientific research of the theme approached is based on the current situation of forests in Romania and the national forest capital. Preventing and combating the criminal phenomenon in the forestry field requires knowledge of specific activities to protect the most important natural resource - the forests. The research methods used for this article are: comparative legal method, statistical method and additional methods of analysis and processing of relevant information, both quantitative and qualitative.

The first mention that, before 1989, the whole forest belonged to the Romanian State. Transferring the forests in the state's heritage, as a good of all the Romanian people, opens the way to a rational management of the whole forestry heritage. The forestry legislation of that time protected the entire forest capital. In the $60 \mathrm{~s}$, the total surface of the forest capital comprised 6.405 hectares.

Romania's forest capital represents $27.3 \%$ of the country's territory, meaning approximately 6.529 hectares in 2013, according to the data presented by the National Institute of Statistics. This rate ranks Romania below the average level of the European Union, which rises to approximately $36 \%$. UE member states such as Finland, Sweden and Slovakia are the countries possessing the largest surfaces of the forest capital, namely $65.5 \%, 62.6 \%$ and respectively $61 \%$ of the territory.

In 2015, the national forest capital registers an increase of 10.534 hectares $(0.16 \%)$, compared to the year 2014, totaling a surface of up to 6.555 million hectares, according to the data presented by the National Institute of Statistics.

Taking into account the fact that the national forest capital is significantly 
important to people, the Forestry Code states that the forest capital "constitutes a good of national interest" and for this matter it is compliant to the forestry law, irrespective of the type of property.

From the trait of "a good of national interest" of the national forest capital results the fact that the rules which govern the specific forestry law have an imperative character. Thus, the national forest capital is compliant to the forestry law, which is governed by the provisions of the article 6 paragraph (1) of the Forestry Code, being defined as "the unitary system of forestry technical, economical and judicial rules regarding the organization, culture, exploitation, protection and security of the forestry capital, with the purpose of granting a sustainable management" [1].

The control of the observance of the forestry law for the national forest capital, with the purpose of guaranteeing its integrity, both for the legal circulation of the respective areas, and in the direction of preventing illegal cutting of trees, belongs to the central public authority responsible with the forestry, through the National Forestry Authority- Romsilva.

The legal protection of forests and of the forestry capital in general, in the context of the environment protection, represents one of the main tasks of the state, of the economic operators and of the citizens.

\section{Forest criminal offences and Romania's national security}

2.1. Aspects regarding to the forest criminal offences

In the last 25 years, we have assisted to an increase of the criminal actions in the forestry field. Unlike other European countries, Romania is the only country in Europe where the surface of the forests suffered a drastic decrease, first of all because of the growth of the criminal phenomenon in the field, but also because of the irrational exploitation of this natural resource.

Illegal cutting of trees, illegal clearings and last but not least illegal retrocessions of forests lead to an ecological disaster. These criminal actions, beside the enormous material damages produced, have serious consequences also from an ecological point of view, not only on short term, but also with long term effects, such as: impact on the health of the population, increased risk of natural calamities, landslides, floods, desert effect and soil erosion, pollution etc. As for what concerns the criminal actions which affect the national forestry capital and the forestry vegetation outside the forestry capital, according to the new Forestry Code adopted by the Law no.133/20155 [2], the category of these criminal actions has been reduced, in the meaning that from the old regulation only the following criminal actions have been kept:

- reducing the national forestry code without observing the legal provisions in force (art.106);

- unrightfully cutting, breaking, destroying, damaging or rooting out trees, seedlings or sprouts of the national forest capital and of the forestry vegetation on areas outside the national forest capital (art. 107);

- grazing in the forests or forested areas where it is forbidden (art. 108);

- stealing trees cut off or broken down by natural phenomena or stealing trees, seedlings or sprouts (art. 109).

We also draw the attention towards the fact that the provisions regarding the forestry criminal offences related to the special marking devices, namely the forestry marking hammers and the instruments used by the forestry staff for marking the trees, the stubs and the timber, stipulated in the art.112-113 of the Law no.46/2008 in the old regulation, are no longer included in the New Forestry Code. The latter confines to stipulate in art. 64 paragraph (1) the legal form of these devices, as follows: "The special marking devices have the legal form of stamps and seals, and their stencils are registered and kept at the notarial offices", while in article 114 of the 
Chapter VI - "Liabilities and sanctions" it is stipulated that "The provisions of the present chapter are completed with the dispositions of the Penal Code and of the Criminal Procedure Code".

Thus, in the case of these special marking devices, the provisions of the articles 317 318 of the Law no. $286 / 2009$ of the Penal Code will be inherent. According to the provisions of the article 317 paragraph (1), "The forgery of a stamp, seal or marking instrument used by the persons mentioned in the article 176 or by the physical persons mentioned in the article 175 paragraph (2) is punished with imprisonment from 6 months to 3 years or with a fine", and in paragraph (2) is stipulated that "The forgery of a stamp, seal or marking instrument used by other persons than those mentioned in the article (1) is punished with imprisonment from 3 months to 1 year or with a fine." The article 318 of the Penal Code stipulates that "Using the forged instruments mentioned in the article 317 is punished with imprisonment from 3 months to 3 years or with a fine."

Obviously, the New Forestry Code is not the only normative act that sanctions forestry crimes. Among the specific regulations regarding the forestry service, we mention the Law no. 289/2002 related to the forest curtains, which regulates in the articles 22-23 the facts which constitute criminal actions and the sanctions to be applied if they are undertaken.

From the data provided by the Institute of Forestry Development and Research in Bucharest - the National Forest Inventory Service [3], within 2008-2014, the volume of illegally cut timber from the national forestry capital and from the rest of the forestry vegetation goes up to the annual average of about 8.8 million cubic meters. According to the data provided by the National Statistics Institute, the authorized and harvested volume within 2008-2014 is of approximately 17.9 million cubic meters per year [4]. The difference of timber mass between the quantity reported by Forestry
Development and Research - the National Forest Inventory Service and the one legally harvested is supposed to be illegally harvested. According to a report of the Court of Accounts in 2013 [5], within 1990-2011, the illegally cut trees rose to 80 million cubic meters of timber, the estimated prejudice being of over 5 million euros.

\subsection{The criminal phenomenon in the forestry field}

In the last years, we have assisted to a destruction of the forests in Romania without taking any measures or promptly reacting against this phenomenon. The crimes in the forestry field registered alarming increases. In many cases, they were undertaken with the help of representatives of judicial organs or public institutions and authorities of the state. Often, the forestry crimes are closely related to other crimes, such as: tax evasions, theft, dilapidation, money laundering and so on, thus the perpetrators come from different fields of activities. Reality proved the fact that in the case of forestry crimes, the perpetrators belong to various social categories and their aggressiveness is determined both by the living conditions, and by fast, sure and constant benefits, resulted from committing such crimes.

The factors generating the criminal phenomenon in the forestry field are numerous: starting with social factors, going to the economic ones, to which we can add the lack of people's education, but also other people's mentality and, last but not least, we mention poverty and the wish to get rich under any circumstances. The prevailing factor is corruption existing at all levels, some people's eagerness of easily gained wealth and the lack of involvement of the government institutions, which were supposed to take measures in this respect. Also the insufficient legislation in the field, as well as the ambiguity of the legislation related to the exploitation and usage of the timber 
mass encouraged the criminal phenomenon.

In time, these factors led to the creation of the favorable conditions for committing illegal actions in the forestry field, whose serious consequences affect not only the population, but also the environment.

\subsection{The forest criminal offences through light the national security of Romania}

In the context of the growing criminal phenomenon, the illegal cutting of trees was the topic laid on the board at the meeting of the Supreme Council of National Defense held in June the $9^{\text {th }} 2015$ [6], when it was established to solve this problem urgently.

Consequently, one of the main directions of action was accelerating the implementation of the Integrated Informational System of Tracking Timber, called SUMAL [7], system which practically consists in monitoring timber in real time, from the moment of marking the trees in the forest, in order to be cut down, to the moment they get to the final beneficiary.

Another direction of action in solving the problem of illegal cutting of trees was to establish the Forestry Guards, according to the G.D. no. 32/2015 regarding the foundation of the Forestry Guards, in order to improve the activity of implementation, monitoring and control in the forestry field, as well as to accomplish the objectives Romania took on, concerning the implementation of the Regulation (EU) no. 995/2010 [8] of the European Parliament and of the Council of October $20^{\text {th }} 2010$. This EUTR Regulation establishes the obligations incumbent on the operators who introduce timber and timber products on the market.

Last but not least, another direction of action in stopping the illegal cutting of timber is the adoption of the Law no. $2 / 2016$ to complete the article 3 of the Law no. 51/1991 regarding the national security of Romania, according to which the destruction of the environment as a result of illegal cutting of timber and of massive deforestation constitutes a new threat to Romania.

The Article 3 of the Law no. 51/1991 regarding the national security of Romania, republished, stipulates the concrete situations which represent threats to the national security of Romania. The mentioned provisions were completed with a new threat, namely: "m) any actions or inactions which trespass against the strategical economic interests of Romania, those which result in endangering, illegal management, damage or destruction of the natural resources, of the forestry, hunting and fishing capital, water and other similar resources, as well as monopoly or blocking the access to them, with national or regional consequences".

Through this measure, public institutions of the state were assigned attributions in the national security field, in order to counterbalance the phenomenon of illegal cutting of forests.

It is well known that the serious consequences of the deforestations, of illegal cutting of trees and of chaotic exploitation of forests have a transnational character, and the results of these actions go beyond Romania's borders.

The phenomenon of illegal cutting of trees is not unique in the European Union, only in our country, but it is present in other member states. However, in our country, this phenomenon is manifested in the most aggressive way, which is the reason why the European Commission drew the attention of our country towards the illegal cutting of trees and required Romania to urgently take the necessary measures to stop it and to apply the EU Regulation concerning timber (EUTR) no. 995/2010.

Knowing the negative effects of illegal actions, both throughout the world and in the European Union, there is a common effort of all the states in order to stop the criminal phenomenon in this field.

The extent of the criminal phenomenon in the forestry field represents a threat for the security of the environment. Numerous alarm signals were drawn by international 
forums concerning the criminal phenomenon which threatens the environment. But the alarm signal drawn by the specialists in the area is that in the following 30-50 years the biggest threat for humanity will be the lack of food resources, as a result of the impact on the soil, thus the agricultural food production being endangered [9].

The destruction of the environment leads to major dysfunctionalities meant to amplify the vulnerabilities of the security. The national security can be granted by decreasing and reducing the vulnerabilities or by preventing threats. In the current context, Romania passes through a period characterized by multiple risks, threats, dangers and vulnerabilities of the national security [10].

Taking this into consideration, we must pay a special attention to the ecological dimension of the national security, because it has the most complex aspect, underlining at the same time its transnational character. We have in view the fact that its effects have no borders, they can be felt in the neighboring countries and in some situations, such as natural calamities, pollution and so on, the effects appear on much more extended areas.

As a matter of fact, the ecological dimension [11] is closely related to the other dimensions of the security: economic, social and cultural. Moreover, the damage of the environment implies a whole series of dysfunctionalities which have as a consequence the increase of the risks, vulnerabilities and threats, not only to Romania, but also to the internal security of the European Union, as comes out from the "The Strategy of Internal
Security of the European Union" [12] which has as main objectives preventing and anticipating the criminal actions, the natural and human disasters, as well as reducing their potential impact.

\section{Conclusions}

One of the priorities of each member state of the European Union must be the protection of the environment, because the deforestations and inappropriate exploitation of forests, as well as the growth of the criminal phenomenon in this field can have extremely serious consequences, such as: destruction of ecosystems, climate change, desert effect and soil erosion, various forms of pollution, poverty, drop of food resources of the population, diseases and so on, which lead to dysfunctionalities meant to increase risks, threats and vulnerabilities of the national security.

The national security can be granted by reducing the above mentioned vulnerabilities or by preventing the threats. In the present context, Romania passes through a period characterized by multiple risks, threats, dangers and vulnerabilities of the national security.

Taking into account the cross-border character of the consequences of deforestations and illegal cutting of trees, we can affirm that all these phenomena are also a threat to the internal security of the European Union, context in which it is necessary to adopt a series of urgent measures in order to counterbalance these negative actions with a devastating impact.

\section{References}

[1] According to the provision 42 of the Annex to the Law no. 46/2008 of The Forestry Code.

[2] ...for modifying and annexing the Law no. 46/2008 - The Forestry Code, published in the Official Gazette no. 411 of June 10th 2015.

[3] http://www.icas.ro

[4] The National Institute of Statistics, http://www.insse.ro 
[5] Romanian Court of Accounts - Audit reporting regarding ,"The heritage situation of the forest capital in Romania, within 1990-2012”, http://www.curteadeconturi.ro/Publicatii/economie7.pdf

[6] http://www.csat.presidency.ro

[7] G.D. no.470/2014 for approving the Norms on the origin, movement and marketing of timber, the regime of timber storage facilities and installations of processing round wood as well as measures for implementing the Regulation (EU) 995/2010 of the European Parliament and Council of October 20th 2010 establishing the obligations of operators who introduce timber and timber products on the market, with subsequent modifications and amendments, (the Official Gazette no. 426 from June 10th 2014); Order no.837/2014 for the approval of the Methodology regarding the organization and functioning of SUMAL, the obligations of SUMAL users, the structure and the means to provide standardized information (the Official Gazette no. 761 of October 21st 2014); Order no.596/2014 regarding the approval of the Methodology for testing the implementation of the Integrated Informational System of Tracking Timber (the Official Gazette no. 491 of July 2nd 2014); http://www.just.ro, http://legislatie.just.ro, www.rosilva.ro .

[8] The Regulation (UE) no. 995/2010 of establishing the obligations incumbent on the operators who introduce timber and timber products on the market; http://eurlex.europa.eu.

[9] Mădălina Daniela Ghiba, Noi ameninţări la adresa securităţii globale (New Threats to the World Security), Buletinul Universităţii Naţionale de Apărare „Carol I” no. 3/2015, Bucharest, Romania, March, 2015, pp.110.

[10] Constantin-Gheorghe Balaban, Strategia securitatii nationale (The National Security Strategy), pp. 8, Editura Academiei de Înalte Studii Militare, Bucuresti, Romania 2001.

[11] Teodor Frunzeti, Vladimir Zodian (coord), Lumea 2007. Enciclopedie politică şi militară. Studii strategice şi de securitate (The World 2007. Political and Military Encyclopedia. Strategical Studies of Security), Editura Centrului Tehnic-Editorial al Armatei, Bucureşti, 2007, pp.92.

[12] www.european-council.europa.eu 